\title{
OPEN
}

\section{Publisher Correction: Structural basis for the inhibitory effects of a novel reversible covalent ligand on PPAR $\gamma$ phosphorylation}

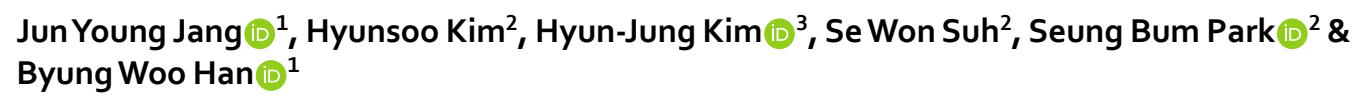

Correction to: Scientific Reports https://doi.org/10.1038/s41598-019-47672-w, published online 01 August 2019

In the original version of this Article, Jun Young Jang and Hyunsoo Kim were omitted as equally contributing authors.

In addition, this Article contained a typographical error in the Results section, under subheading 'Covalent binding mode in the SB1495- and SB1494-bound PPAR $\gamma$ structures'.

"In order to compare the covalent binding modes of SB1495 and SB1494 with other covalent PPAR $\gamma \gamma$ ligands, we superimposed SB1495- and SB1494-bound structures with a total of 22 covalent ligands for PPAR $\gamma$ LBD deposited in Protein Data Bank (PDB) so far ${ }^{8,17,24-29}$."

now reads:

"In order to compare the covalent binding modes of SB1495 and SB1494 with other covalent PPAR $\gamma$ ligands, we superimposed SB1495- and SB1494-bound structures with a total of 22 covalent ligands for PPAR $\gamma$ LBD deposited in Protein Data Bank (PDB) so far ${ }^{8,17,24-29, "}$

These errors have now been corrected in the PDF and HTML versions of the paper.

(i) Open Access This article is licensed under a Creative Commons Attribution 4.0 International License, which permits use, sharing, adaptation, distribution and reproduction in any medium or format, as long as you give appropriate credit to the original author(s) and the source, provide a link to the Creative Commons license, and indicate if changes were made. The images or other third party material in this article are included in the article's Creative Commons license, unless indicated otherwise in a credit line to the material. If material is not included in the article's Creative Commons license and your intended use is not permitted by statutory regulation or exceeds the permitted use, you will need to obtain permission directly from the copyright holder. To view a copy of this license, visit http://creativecommons.org/licenses/by/4.0/.

(c) The Author(s) 2019

\footnotetext{
${ }^{1}$ Research Institute of Pharmaceutical Sciences, College of Pharmacy, Seoul National University, Seoul, 08826, Republic of Korea. '2Department of Chemistry, College of Natural Sciences, Seoul National University, Seoul, 08826, Republic of Korea. ${ }^{3}$ College of Pharmacy, Chung-Ang University, Seoul, 06974, Republic of Korea. Jun Young Jang and Hyunsoo Kim contributed equally. Correspondence and requests for materials should be addressed to S.B.P. (email: sbpark@snu.ac.kr) or B.W.H. (email: bwhan@snu.ac.kr)
} 